\title{
Connection and Constitution: Locating War and Culture in Globalization Studies
}

\author{
TARAK BARKAWI
}

University of Cambridge

ABSTRACT War and the military are neglected in globalization studies, despite the fact that the worldwide circulation of people, goods and ideas often takes warlike form. This article seeks to remedy this neglect by conceiving war itself as a form of interconnection between peoples and locales, and as an occasion for circulation and interchange. The article develops a multidimensional and historical conception of globalization as relations of connection and mutual constitution, and locates war and culture within them. Cultural approaches to globalization are used to illuminate the role of war and the military in consciousness of the world as a whole and to address the significance of military 'traveling cultures'.

The end of the Cold War saw the rise of globalization as a frame for conceiving world politics, for scholars, politicians, policy analysts and the public. Alongside the neoliberal 'globalist' agenda that framed much discussion in policy and media circles, a diverse and multidisciplinary scholarly literature developed with extraordinary rapidity. Liberated from the peculiar confines of the discipline of International Relations (IR), with its obsession for sovereignty and relative neglect of social relations, a rich and exciting body of thought concerning the 'international' broadly conceived has grown around the globalization concept, with economists, sociologists, anthropologists and historians as well as political scientists making important if sometimes contradictory contributions. IR took as its central problem the question of war and peace. By contrast, with some important exceptions, in globalization studies relatively little attention is paid to war, despite the frequency of armed conflict since 1989.

Where war is considered, it most often is understood as a separate and distinct phenomenon from globalization. There is for example a debate over whether or not economic globalization promotes peace or causes war (Schneider et al., 2003). Al Qaeda is sometimes conceived as

Correspondence Address: T. Barkawi, Centre for International Studies, Cambridge University, Cambridge, UK. Email: t.barkawi@ntlworld.com 
resisting Western globalization (Mandelbaum, 2002; see also Black, 2004, pp. 3-4 on 'counterglobalism'). More promising are efforts to conceive globalization as the worldwide social terrain of contemporary armed conflict. ${ }^{1}$ This essay seeks to theorize war as a pervasive and historically significant form of international interconnectedness, as a globalizing force. In and through war, peoples come to intensified awareness of one another, leaderships initiate and react to each other's moves, and armed forces and other populations circulate. To be at war is to be interconnected with the enemy. Such connections lead to social processes as well as political and cultural transformations that are usefully understood through the globalization concept.

The first step is to critique the pacific tendencies of globalization studies. In diverse and significant ways, globalization is defined in terms of flows which qualify, or even fatally corrode, a world of nation-states (Appadurai, 1996; Ohmae, 1994; 1996; Tomlinson, 1999). At the same time, nation-states are typically conceived, implicitly or explicitly, as the site of the problem of war in world politics, despite widespread histories of imperial violence in modern times. In neoliberal formulations in particular, globalization is seen as considerably ameliorating the problem of war among nation-states (e.g. Weede, 2003). Such economistic readings of globalization are blind to the roles of the state and coercive power in creating and maintaining a free trading world, a recovery of which is the burden of the discussion immediately following this introduction.

The pacificity of globalization studies extends well beyond the liberals, who long have been unable to conceive their own implication in violence. The most sophisticated discussions of globalization are found among social and cultural theorists (e.g. Castells, 2000; Clifford, 1997; Robertson, 1992; Tomlinson, 1999), but here too there is relatively little explicit attention to war or even other political violence (although cf. Appadurai, 1996, chaps. 7-8; Shaw, 2000). Why is this, given the ubiquity of war and political violence since 1989? In contrast to liberal conceptions of globalization, elsewhere in the academy assumptions about peace and globalization are more implicit in nature. They are part and parcel of social and political theories which rarely reserve for war-one of the most persistent and widespread of human phenomena-a central role (Shaw, 1988). As Hans Joas argues, modern social theory largely fails to grapple with the centrality of war for modernity: 'The major theories that are the subject of general discussion today-let us take Habermas, Luhmann or the poststructuralists as examples-contain hardly any mention of war and peace' (2003, p. 126). Globalization studies largely partook of this milieu, until confronted with $9 / 11$ and the war on terror. The inattention to violent conflict impoverishes our understanding of the social and cultural dimensions of globalization. Force and war made possible many of the processes we associate with globalization broadly conceived, for example by joining up the world during the period of European expansion. As important are the distinctive social and cultural processes set in train by violent conflict itself.

That said, social and cultural as well as historical approaches to the globalization concept provide the essential foundations for theorizing war and globalization. They do so by conceiving globalization as multi-dimensional, as consisting of social and political as well as economic flows, and by emphasizing the centrality of culture, conceived as structures of meaning. Before realizing this contribution, the all too common trope of a world of flows corroding a world of territorial states must be dealt with decisively. In focusing on global flows held to be corrosive of territorially defined entities, globalization studies lost sight of war. Implicitly, war here is misconceived as a breakdown of communication and interchange, rather than as an occasion for circulation. Attention to flows should illuminate the nature of war, for war works its effects precisely through interconnection. Relatedly, in opposing flows to a world of territorially defined entities, globalization studies overlooked the role of flows in constituting 
such entities. This is one reason for the presentism of much that has been written on globalization-globalization is seen as succeeding a world of nation-states. By contrast, 'globalization' can be taken as referring to the 'thick' set of mutually constitutive international relations out of which apparently discrete entities such as nation-states are produced, reproduced and transformed. War and its related social and cultural processes are significant components of this field of mutually constitutive relations.

\section{Globalization, Liberalism and Force}

Between 1989 and the strikes of 11 September 2001, globalization was very closely associated with a hegemonic neoliberal ideology known as 'globalism' (Steger, 2002). The basic claims were that the intensification of international trade and investment had reached a point at which national economies were dissolving into a 'global economy determined by world market forces' and that the only viable public policy was one that continued to deregulate trade, investment and capital movements while dismantling the social welfare state (Hirst and Thompson, 1999, p. xii). While the globalists focused on the utilitarian calculus of increased wealth promised by 'globalization', the period after the Cold War also saw the re-invigoration of other strands of liberal thinking. For classical liberals, free trade abroad as well as liberal governance at home boded well for another, potentially greater benefit than wealth: peace.

For Adam Smith, the most important consequence of the rise of commerce and manufacturing was that they introduced order and good government, which created the conditions for liberty and security 'among the inhabitants of the country, who had before lived almost in a continual state of war with their neighbors' (1993 [1776], p. 260). Agitating for an end to the Corn Laws in 1843, Richard Cobden held that bringing down barriers to trade also brought down barriers between nations, 'those barriers behind which nestle the feelings of pride, revenge, hatred and jealousy ... feelings which nourish the poison of war and conquest' (quoted in Howard, 1987, p. 43). A very similar logic is at work in President G.W. Bush's call for a US-Middle East free trade zone in the wake of the US conquest of Iraq which, he argued, would 'drain the bitterness' from the region and increase US security. 'Over time, the expansion of liberty throughout the world is the best guarantee of security throughout the world. Freedom is the way to peace. ${ }^{2}$

A variety of mechanisms were proposed through which liberalism would end war. Ever since Smith's critique of mercantilism, it was hoped prospects of increased profit through free trade would overcome the desire for outright conquest. For Immanuel Kant, peace was to come about through the territorial spread of republican governance and rule of law (1983 [1796]). With the end of the Cold War, the pacifying promises of a resurgent liberalism found new voices. For Francis Fukuyama (1992), liberal democracy met both the material and ideal needs of humans, and hence promised an end to the history of great ideological struggles and its wars. Political scientists in the United States constructed a statistical law to the effect that liberal democracies did not fight wars with other democracies, a proposition used by President Clinton and others to justify 'exporting democracy' (Russett, 1993; cf. Barkawi and Laffey, 1999).

Hopes for a new world politics fostered by the collapse of the Soviet bloc represented a return to well-worn liberal themes. Unsurprisingly, these hopes betrayed some of the same tensions and blind spots with respect to war and force that characterize liberal thought. For classical liberalism, wars were essentially atavistic, 'the relics of a dying age that had not yet been illuminated by the dawn of the Enlightenment' (Joas, 2003, p. 30) As 'Reform' and 'Progress' overcame 
despots and the warrior castes of the aristocracy, and free trade fuelled prosperity, wars civil and foreign would pass into history. Easily obscured from view in this vision of a pacific liberal modernity is the role of force in making liberal the illiberal as well as specifically liberal tendencies to war, that is, those tendencies to war generated in a world being made liberal and modern in diverse and important ways (on liberal modernity, see Latham, 1997, chap. 1).

In particular, European imperial expansion, which involved widespread use of force, was fundamental to the creation of the modern international economy. Imperialism set in train modernization processes which generated, and continue to generate, social and political tensions which often take violent form. Creating and maintaining a free trading word required repeated and sustained use of force. While most often this took the form of Western military intervention in the non-European world, Anglo-American victories in the two world wars were vital as well. Genocides of aboriginal peoples were a significant dimension of these processes. These forceful processes provide the essential social, political and cultural context of modern globalizations; it is in and through these processes that the world as a whole was joined together in recognizably modern form.

While liberalism, in so far as it characterizes world politics, owes important debts to colonialism, genocide and total war, the categories of liberal thought are not well-suited to analysis of imperialism, force and war. Yet these categories are pervasive in elite, scholarly and popular discussion of world politics, especially but not only during the period after 1989, and no where more so than in popular, media and elite discussions of 'globalization'. In many ways, particularly as regards the contemporary international economy and the international legitimation of the use of force, liberal categories largely set the terms in which debate is conducted, or at least they did so prior to the war on terror. Many thinkers have argued in different ways that liberal thought obscures and elides critical aspects of the operation of power and force in world politics (e.g. Carr, 1939; Schmitt, 1996 [1932]). To the extent, then, that discourses of globalization reflect and embody liberal categories, similar obfuscations are likely to occur. In particular, there is an apparent difficulty, even among staunch critics, to see the forceful foundations that made possible a free trading world; and, second, a long-standing resistance to recognizing the central dependence of capitalist economies, at home and abroad, on state regulation, ultimately backed up by 'legitimate' force. In order to locate war and culture in globalizing processes, these histories must be recovered.

In discussing aspects of European expansion, two of the earliest critics of economic globalization wrote: 'The cheap prices of [the bourgeoisie's] commodities are the heavy artillery with which it batters down all Chinese walls, with which it forces "the barbarians" intensely obstinate hatred of foreigners to capitulate.' It was apparently with metaphorical heavy artillery that the bourgeoisie created 'a world after its own image' (Marx and Engels, 1967 [1888], p. 224). To be sure, Marx and Engels were acutely cognizant of the 'structural violence' associated with capitalist development, but force and war have their own logics which must be attended to. They perhaps had the first Opium War (1839-1842) in mind. In the decisive campaign of that conflict, some 25 Royal Navy ships of the line, 14 steamers and nine transports carrying 10,000 troops were required, a considerable expeditionary force for the time (Porch, 2001, 73). The defeated Chinese state was forced to sign a number of unequal treaties with the British and other European powers which sought to facilitate the expansion and deepening of circuits of merchant capital (Cain and Hopkins, 2002, pp. 362-8). In turn, the Europeans sought afterwards to support a now more pliant Chinese government against internal uprisings generated in part by the increased presence of the Europeans and their products. Such resistance required repeated applications of force over the following decades, sometimes directly by the Europeans 
themselves and sometimes by the armies of their Chinese clients, advised and supported by Europeans, a far different consequence of the growth of manufacturing and commerce than Adam Smith imagined.

The tendency to see free trade as a kind of non-violent imperialism is nonetheless particularly strong (Gallagher and Robinson, 1953). In discussing the developing American imperial role, Reinhold Niebuhr remarked in 1931 in an article entitled 'Awkward Imperialists' that 'we are the first empire of the world to establish our sway without legions. Our legions are dollars' (quoted in Reynolds, 2002, p. 245). In 1931, American marines were fighting Augusto Sandino in Nicaragua and ruling Haiti and US troops were also in the Philippines and China. At the same time, the Roosevelt administration was putting in place the system in Central America by which US influence was exercised through authoritarian clients and their security forces, trained, supplied and advised by the United States, a system whose long and violent history lasted to the 1980s (La Feber, 1984, pp. 78-83). The repression of leftists and other popular forces made possible the neoliberal Central America of the 1990s. Even so, despite 70 more years of widespread military intervention since Niebuhr's remarks, much of it designed to establish and defend regimes considered friendly to the 'free world' and open to the international economy, Prime Minister Mahathir was still telling his compatriots at the first South Summit in April 2000 that 'capital is the new gunship of the rich' (quoted in Harper, 2002, p. 141). These remarks were made in Cuba, the site of repeated US military and covert interventions. More recently, the six aircraft-carrier battlegroups used in the invasion of Iraq are a reminder that as important as finance capital is, warships still play a role in attempts to export 'democracy' and maintain the capitalist world economy.

This brief discussion of liberalism, imperialism and force is intended only to provide an idea of the foundational role and long and on-going history of military intervention in processes of capitalist expansion, as well as some of the ways in which this history has been obfuscated. What points can be drawn from this discussion in respect of much of the literature on contemporary economic globalization, the ideology of globalism and the location of war and culture in globalizing processes? First, it draws attention to the historically variable, international political-military structures required to expand and maintain 'free trade'. These structures involve state regulation, with both local and international elements, and historically have depended on repeated use of force (again, both local and international) to crush resistances. Economic globalization, it turns out, is a political project, one that makes use of force as well as other instrumentalities (Gray, 2002).

Coercive power is only one, albeit essential, element of processes of political globalization through which economic globalization is made possible. As Leo Panitch (1996), William Robinson (1996) and Martin Shaw (2000) have argued in different ways, the state is not undermined or overwhelmed by globalization, but transformed by it, and as such becomes a critical agent of globalization, a formulation which applies as much to the Chinese state after 1842 as it does to the Canadian state after signing NAFTA. Local states are re-fashioned to facilitate capital and, in the contemporary world, an overarching 'international state' - a messy agglomeration of state-like institutions such as the WTO-regulates the system as a whole. The concepts and history needed to assess these political and military dimensions of contemporary globalization are simply absent in neoliberal readings, which focuses on the undermining or curtailing of the role of the state. Locating war and related cultural phenomena in processes of globalization requires attending to these political-military structures.

The second point to be made from the discussion of imperialism relates to specifically liberal and modern tendencies to war. China's troubled history after the Opium War is evidence that 
opening markets, and the modernization processes set in train by European expansion, are generative of social and political tensions which frequently issue in violent rebellion and war. A 'national history' of these events in China might dwell on the long series of rebellions against the Manchu dynasty, its successors and the European presence which ultimately culminated in the victory of the Communist Party. Such a national history could well miss the fact that from the Opium War, there was an intensified intertwining of Chinese, European and later American histories (e.g. Cohen, 1985; cf. Duara, 1997; Karl, 2002). Elements of this complex and multifaceted process are easily grasped, such as the ways in which exporting Indian opium to China righted a balance of payments problem that resulted from European imports of Chinese tea and spices.

More relevant here are the ways in which this intertwined history continued to be generative of violent conflict and its related cultural processes for China and the metropole. The People's Republic of China played a major role in the Asian land wars of the Cold War, wars that involved Britain, France and the United States and which had more or less major domestic political, social and cultural ramifications in each of those countries. The 'loss of China' holds a special place in the domestic US political and social history of the Cold War, helping to spawn McCarthyism. With Chinese intervention in the Korean War, the media fracas surrounding the US POWs from that war who voluntarily remained in the PRC afterwards, and the film The Manchurian Candidate (dir. John Frankenheimer 1962) among others, China came to play a role in US Cold War popular culture as well (Carruthers, 1998a; 1998b).

These examples begin to suggest just where war and culture might be found in processes of globalization. Crucially, any solely national history of one or another country would likely miss the interactive, interconnected worldwide dynamics through which violent conflict is generated and its effects proliferated. Attending to the political-military not only enriches understandings of globalizing processes but also enables new perspectives on the relations between war, society and international relations. Equally, the interconnections between strategic and cultural histories apparent in the consequences of the PRC's Cold War role for American society, or in the effects of the Vietnam conflict on American culture, suggests that the academic separation of cultural and strategic studies is misconceived, and that the globalization concept offers one way to overcome it (Barkawi, 2004).

This turn to the idea of worldwide dynamics, multi-dimensional in nature-economic, political, military, cultural, social—requires refiguring our understanding of 'globalization'. Neoliberal readings of globalization cannot conceive either the political and military dimensions of contemporary economic globalization or its imperial foundations. The histories of worldwide 'free trade' are nonetheless an essential context for locating war and culture in processes of globalization. But in order to adequately analyze such processes, a more multi-dimensional concept of globalization is necessary.

\section{Globalization, Constitutive Circuits and War}

A critical grasp of contemporary neoliberal globalization involves the history of European imperialism and the multi-dimensionality of the forms of interconnection between core and periphery that resulted. Moving beyond economic globalization, scholars developed approaches which capture relations of transregional interconnectedness in all their diversity. Specific formulations vary with author and discipline but broadly speaking this literature deploys a notion of globalization as interconnection across borders, 'a stretching of social, poli-

tical and economic activities across frontiers such that events, decisions and activities in one 
region of the world can come to have significance for individuals and communities in distant regions of the globe' (Held et al., 1999, p. 15). These approaches make possible the analysis of globalizing processes in different historical eras as well as of non-Eurocentric globalizations (Hopkins, 2002).

Nonetheless most efforts along these lines retain a strongly presentist focus. In particular, they rely explicitly or implicitly on a narrative which associates globalization with developments in modern communications technologies and the compression of time and space (e.g. Appadurai, 1996; Castells, 2000). It is the relatively recent intensification of the circulation of people, goods and ideas around the world that produces 'globalization'. Globalization is something that happened to a world composed of relatively discrete, separate entities, or at the least to a world of entities not previously connected in equivalent ways.

It is beyond question that recent developments in communications technologies have given contemporary globalizing processes a velocity and character different from those of other eras. However, it is important not to conflate the attributes of globalizing processes at one point in history with the concept of globalization as such. Globalization is often used to refer to relations of interconnection, as in 'complex connectivity'. These relations are seen, in diverse ways, as profoundly transformative of the societies involved. This idea of interconnection is frequently bound up, more or less immediately, with an additional thesis, concerning the dependence of these processes on modern communications. So for example, John Tomlinson writes: 'globalization [is] an empirical condition of the modern world: what I shall call complex connectivity. By this I mean that globalization refers to the rapidly developing and ever-densening network of interconnections and interdependencies that characterize modern social life' (1999, pp. 1-2). Interconnection is articulated, via 'rapidly developing' and 'everdensening', to modern communications technologies.

The approach to globalization favored here takes the first aspect of these definitions-interconnections-and goes one step further. If globalization is transformative, it is also constitutive. However, the second aspect, the dependence of globalization on modern communications, is called into question. This is not to deny that modern communications are crucial to the nature of contemporary globalization. Rather, what is challenged is the idea that globalization as such is dependent upon these technologies. If globalization is about constitutive interconnection between peoples, locales and political entities in world politics, does such connection require jet travel and satellite TV?

Consider C.L.R. James' account of Toussaint L'Ouverture and the San Domingo revolution, The Black Jacobins (1994 [1938]). James lays out the complex inter-relations between the Haitian and French Revolutions: 'James was interested in the political, economic and intellectual aspects of this cross-over: how events in both locations affected each other, shaped what happened and defined what was possible' (Hall, 2002, p. 9). The title of James's study alone is indicative of the intertwined developments and hybrid identity constructions involved. This 'stretching' of social relations occurred by means of sailing vessels, matching in form Held et al.'s definition of the metaphor. Following in James' footsteps, there is now a very large literature tracing out the mutual constitution of metropole and colony in the era of European imperialism (e.g. Cooper and Stoler, 1997; Hall, 2000; Wolf, 1997). While much of this literature does not explicitly invoke the globalization concept, its themes of multi-dimensional transregional interconnectedness, hybrid cultures and common histories are very similar to the claims made for contemporary globalizing processes by cultural theorists. The hybrid identities of the denizens of Paul Gilroy's 'Black Atlantic' (1993) were in process long before nearinstantaneous inter-continental electronic communications. 
The literature on imperial interconnections can conceptually clarify that on contemporary globalization. The key claim is that metropole and colony cannot be understood one without the other, they comprise a 'single analytic field' (Cooper and Stoler, 1997, p. 4). 'What we now call Europe, Africa, the Americas and Asia were constructed together in the midst of a relationship, at once economic and cultural, military and political' (Drayton, 2002, p. 103). The relations of interconnection are theorized as constitutive relations, whether one is looking at European society, economic power, military power, political thought, or culture and identity (e.g. Echenberg, 1991; Inayatullah and Blaney, 2004; Jahn, 2000; Wolf, 1997). Gilroy does not conceive the history of black slavery as the property only of Afro-Caribbeans, or AfricanAmericans or even of Africans alone, for this history 'has a great bearing on ideas of what the West was and is today' (Gilroy, 1993, p. 45). Frantz Fanon put the point succinctly, 'Europe is literally the creation of the Third World' (1967, p. 81). And vice versa, it must be added. Apparently discrete entities in world politics-such as colonies, states and national societies-are produced out of fields of mutually constitutive relations. In a roundabout way, the debate in and around globalization and empire has led to a fully fledged conception of the 'international', as a dense field of relations, as the wider social context productive of the communities and other entities that populate world politics.

The essence of the claim here is that 'globalization' be taken as a general term referring to relations of interconnection and mutual constitution in world politics. It is in this loose sense that the term is often used in globalization studies. As such, it is potentially applicable to any era in history, not just the contemporary one. Excellent examples of globalization can be found in the periodic eruptions of nomadic soldiers in Africa and Eurasia from the ancient world through to the eighteenth century. The armies of Alexander the Great and Attila the Hun were 'genuine agents of global change', creating new political entities and commercial links while destroying or disrupting old ones (Bayly, 2002, p. 57). Certainly this kind of 'warrior globalization' is very different from the contemporary version, but it does involve transregional relations of interconnection, transformation and constitution. Such historical globalizations, however, are not truly 'global' in scope. A rough and ready definition of globalization as connection and constitution serves well for the discussion of war immediately below but in the conclusion of this section, Roland Robertson's (1992) critique of such an expansive view of globalization will be considered.

If globalization refers to international relations of connection and constitution, war is a significant dimension of these relations. A promising place to begin is with the "war and society' approach (e.g. Bond, 1998; Howard, 1976). The core idea here refers to the ways in which wars are shaped by the societies which wage them, and how societies are shaped by the wars they wage. The character of a war is shaped by its larger social context and in turn war reacts back on its social context. For example, new forms of mass involvement in politics enabled Revolutionary and later Napoleonic France to mobilize very large armies. Social and political developments shaped the character of the Napoleonic wars, but the reverse is also true. Ancien régime states were forced to make adaptations to compete with France. Clausewitz captures the interactive dynamics: 'Since Bonaparte, then, war, first among the French and subsequently among their enemies, again became the concern of the people as a whole ... War, untrammeled by any conventional restraints, had broken loose in all its elemental fury' (1976, pp. 592-3).

Underlying Clausewitz's analysis is the idea that war is generative; it operates on the larger social context, transforming it in diverse ways, in a dialectic between war and society. Additionally, war is interactive. Adequate histories require tackling all the sides to get a sense of how 
and why events developed as they did. 'War contains a host of interactions' (Clausewitz, 1976, p. 582). War conjoins the societies involved in constitutive circuits. ${ }^{3}$ Wars develop and take shape as an intertwined history. As this is a general property of war any number of examples can be cited.

Before doing so some objections and caveats require attention. One objection to re-labeling the history of war 'globalization' is that it amounts to just that, a re-labeling of well-known events. The globalization concept is doing no valid theoretic work, it is simply redescribing the social processes of warfare. While there is superficial truth in this claim, it is wrong. Globalization draws our attention centrally and specifically to the domain of interconnection, to interactive processes and their consequences. Studies of war by historians, political scientists and others do not generally foreground this dimension, although neither is it entirely overlooked. A second issue is that major war between great powers is productive of new international orders, as Philip Bobbitt has recently argued (2002). Military victories combined with consequent developments in international law and international organization regulate the affairs of states (see also Schmitt, 2003 [1950]). This line of analysis is a very important one to pursue, especially as regards developments during and after the Second World War which laid the basis for the 'international state' and contemporary forms of economic and political globalization. This is not, however, what is at stake in this essay, which focuses on the constitutive properties of interconnections occasioned by war, a more general and different theoretic claim. Finally, many of the examples used below refer to wars between core and periphery, that is between powers located in the global North and those in the South, or to imperial aspects of great power war. This is partly reflective of the interests of the author but also of much of the globalization literature, which has focused on relations between North and South. More importantly, such examples draw attention to how wartime interconnections between powerful and apparently insignificant, weak countries can have major consequences, both for the societies involved and beyond.

Perhaps nowhere is this feature of such wars more evident than in American involvement in Indochina. The Tet offensive in early 1968 is just one route into this intertwined, interconnected history. The offensive occurred three years after the introduction of American ground combat forces into South Vietnam, during which the United States had claimed steady progress. Following rosy predictions of light at the end of the tunnel, Tet came as a rude shock to the American public. Public trust in the veracity and authority of the US government was shaken in ways which were never fully recouped. The irony was that, in strictly military terms, the Tet offensive was a serious defeat for the Vietnamese communist forces.

After the war the Vietnamese commander, General Vo Nguyen Giap, commented with benefit of hindsight that with Tet 'we wanted to carry the war into the families of America' (quoted in Karnow, 1984, p. 557). Via the medium of the war, Giap and his forces reached out and exercised a constitutive role in US society and politics. In turn, the altered social and political landscape in the United States reacted back on the war, as US commanders were obliged to move with renewed intensity towards 'Vietnamizing' the war and seeking an exit for US forces. Constitutive circuits ran in and through the societies at war, conjoining them and shaping developments on the home fronts and at the war front. These circuits spiraled out in time and space as well, extending far beyond the war and even the combatant societies. The importance of the Vietnam experience for American politics, society and culture in the last quarter of the twentieth century is difficult to overestimate. The extent, diversity and significances of Vietnam Warrelated cultural phenomena in US society are quite extraordinary (e.g. Bates, 1996; Jeffords, 1989). Vietnam was also a searing experience for the US national security establishment. 
'Lessons' were learned which shaped future US force projection, and hence the character of future wars. The strategy adopted to evict Iraqi forces from Kuwait was an embodiment of the Vietnam-derived Powell/Weinberger doctrine. A different application of the lessons of Vietnam shaped US involvement in Bosnia and Serbia (Ó Tuathail, 1996, chap. 6). 'You don't want to be Lyndon Johnson', one of President Bill Clinton's advisors told him, 'sacrificing your potential for doing good on the domestic front by a destructive, never-ending foreign involvement' (quoted in Morris, 1997, p. 245).

The choice of Vietnam to illustrate the international relations of connection and constitution set in motion by war might be seen to work against the idea that globalization is not dependent on modern communications technologies, given the emphasis on television news and other forms of modern visual culture in accounts of US involvement in Indochina and its consequences. Certainly, the media are crucial to understanding representations of the Vietnam War in US society. However, contemporary communications technologies are not necessary to the constitutive circuits connecting war and society. Julius Caesar and his legionnaires returned in $50 \mathrm{BC}$ from their conquest of Gaul abroad to put an end to the Roman Republic at home, as the "very success of imperial expansion had thrown the social and political order at home into crisis' (Keegan, 1993, p. 273). Benjamin Disraeli came to power in 1874 promising imperial adventures, an electoral strategy that appealed to the newly enlarged British electorate. Despite the absence of television news, his government collapsed in 1880, in part due to William Gladstone's denunciations of the Afghan and Zulu wars: 'Remember the rights of the savage!' Gladstone told his audiences (quoted in Porch, 2001, pp. 41-2). Lyndon Johnson was neither the first nor the last leader of a powerful metropolitan state to suffer from military imbroglios in apparently insignificant countries, as Gladstone himself was to discover in the Sudan in 1885 and the Italian prime minister Francesco Crispi a decade later, upon the near-annihilation of an Italian army by the Ethiopians at Adowa in 1896.

To sum up the analysis of the essay so far, 'globalization' is popularly understood as a primarily economic and economistic process through which a global economy has come into being. Such understandings overlook the role of politics and force in creating an economically globalized world. Attention to the role of force in opening markets draws attention not only to its foundational role in expanding free trade but to diverse and significant feedback loops set in train by the exercise of military power, in and through which metropole and periphery are conjoined by war and its consequences. War and its cultural effects are here located in processes of economic globalization. In order to address these effects directly, however, a multi-dimensional approach to the globalization concept is required. This involves refiguring it as a term which refers to the international as a socially 'thick' space, as consisting of fields of mutually constitutive relations riven through with relations of hierarchy and domination. So refigured, it can be seen that war is an important element of these fields of relations, a form of interconnection with constitutive effects for the parties to the conflict and beyond. The example of the United States in Vietnam was used not only to show the interactive effects of war on the societies involved-constitutive circuits-but also to gesture towards the effects of the Vietnam War on later uses of force, and thus how that war continues to exercise a constitutive role in world politics.

At this point, a concern needs to be raised regarding the mutation of globalization into 'international relations of connection and constitution', as it would seem that the 'global' in globalization is being neglected. There is slippage between the idea of 'transregional interconnectedness' and a truly global stretching of social relations. At what scale should international processes of mutual constitution be considered under the rubric of globalization? Interestingly enough, the most obvious candidate for a global globalization, the global economy, is simply 
not global. Contemporary trade, investment and financial flows are heavily concentrated in Japan, Western Europe and North America (Hirst and Thompson, 1999, chap. 4). Equally, arguments that the world is becoming a single cultural and social setting, or 'global unicity', in the strong sense of common global society or culture are overdrawn (e.g. Ohmae, 1994). Globalizations, it would seem, have always been partial in terms of scale and consequences. However, it is arguable that a genuinely global image of the world came about as a result of European exploration, imperial expansion and associated cartography. It became possible to imagine the world as a single place in new ways, even if there was not a single world culture. These developments allow a different approach to the idea of global unicity and processes of globalization, of the kind that Roland Robertson (1992) has developed.

Robertson's argument is that relatively long term processes of time/space compression have increasingly made the global the frame of reference for human thought and action. It is in large measure on this cultural basis that he argues 'globalization' should be distinguished from mere transregional interconnectedness, of the kind found in the ancient world (Robertson, 1992, pp. 182-3). Societies and cultures became globally 'contextualized', reflexively comparing their own ways to others, a process Robertson calls 'relativization' (Robertson, 1992, pp. 26-9; Turner, 1994, p. 111). Japanese modernizers in the late nineteenth century, for example, were acutely aware of other models of modernization; while in the second half of the twentieth century, for a time, Japan itself became a model of economic development for others (Robertson, 1992, pp. 85-96). Different ways of organizing politics, society and economy are assessed relative to one another, as people become reflexively aware of alternatives and their potential global consequences. Globalization does not necessarily produce global sameness but rather reflexive awareness of one's location in globalizing processes as well as of one's prospects relative to others.

For Robertson, the compression of the world can lead to 'an exacerbation of collisions between civilizational, societal and communal narratives' (1992, p. 141). Robertson here maps out possibilities for a theory of contemporary globalization and conflict, which locates ethnic assertion and violence within, rather than against, globalizing processes (see Appadurai, 1996, chaps 7-8 for an elaboration). Contemporary efforts to assert a local, 'traditional' identity in the face of the global are thus an aspect of globalization, not a countervailing trend. 'Acting (and thinking) globally is increasingly necessary in order make the very notion of locality viable' (Robertson, 1992, p. 172). The desire for a local identity, the search for a home, are themselves globally diffused ideas that arise from awareness of difference and in reaction to modernization and rationalization processes. Moreover, time/space compression, and other consequences of modernity, in particular the possibility of the destruction of humanity through nuclear war, global warming or some other apocalyptic scenario, increases concern with the fate of humanity. 'Globality-defined in the immediate context as consciousness of the (problem of) the world as a single place-appears increasingly to permeate the affairs of all societies and multitudes of people across the world' (Robertson, 1992, p. 132). But for Robertson, to be conscious of the world as a single place does not mean that there is a shared response to the problems posed, or even a shared analysis as to what those problems might be.

Robertson has produced a sophisticated and subtle position on globalization, which this brief overview does not do justice to. Globalization in his terms is a specific, multi-dimensional historical process, which is genuinely global, tied very closely to the rise and expansion of the West, and which he dates from the early fifteenth century (Robertson, 1992, p. 58). It stands in some degree of opposition to the looser conception used above, which refers more generally to the ways in which localities and entities in world politics are produced and reproduced in 
and through mutually constitutive relations with one another. However, in the final section below, Robertson's emphasis on consciousness of the world as a whole will be taken seriously. What is the place of warfare in the evolution and intensification of this consciousness?

\section{War, the Military and Consciousness of the World}

Cultural frameworks and understandings produced in and through war and military service are integral to the ways in which people experience their everyday lives and situate their localities in the wider world. These war-related structures of meaning naturally take different form across time and space. Because of the prevailing view that globalization is corrosive of the nationstate and national identity, there is a tendency to overlook the relational character of nationalism as well as the value of cultural approaches to globalization in illuminating it. Nationalists contextualize their nation in a world of other nations, some threatening, some friendly. As a consequence, in a world organized on 'national-international' lines (Robertson, 1992, p. 154; Shaw, 2000, chap. 2), comparison of relative military power is a basic form of awareness of other societies in the global field, at elite and popular levels.

That is, 'relativization' in Robertson's terms has a powerful military dimension. Consider for example the Royal Navy's 'two power standard' in the latter part of the nineteenth century, the idea that it had to be equal or superior to the combined forces of the next two largest navies (McNeill, 1982, p. 275). After the Cold War, the US military developed a similar notion, that it had to be able to fight two regional wars at the same time. In both the UK and the United States powerful popular cultures of nationalist militarism undergirded military preparedness. As David Campbell (1992) argues, the representation of foreign danger is a key moment in national identity construction and transformation. The point here is that the outside world is inherent in these nationalist projects, that forms of cultural interconnection can be as productive of national chauvinism as they are of cultural hybridity. Campbell (in his classic Writing Security [1992]), and Cultural Studies more generally (e.g. Renda, 2001), tend to focus only on one nation, typically the United States, and how representations of the foreign play a role in identity construction. What is lost here is the interactive nature of these processes. Cultural representations of, say, Vietnam, in the United States are related to events there and the actions of the Vietnamese, such as the Tet offensive. Hence the context of these representations is in fact international or global, yet this is easily lost in nationally focused studies, where the outside world too easily is seen as merely the figment of national imaginations (cf. Barkawi, 2004). War, consciousness of the wider world, and the interactive processes that follow, are inherent in 'national' cultural phenomena.

To be sure, war and the military play important roles in national constructions of self and other. But some mention should be made of a different form of military consciousness of the world that involves border crossings and hybridity. Commentators and critics of contemporary globalization often note that worldwide travel is still very much an elite occupation, with the exception of certain forms of tourism (Tomlinson, 1999, pp. 8-9). But commoners have long traveled the world as soldiers. Alexander the Great's army marched through Persia to India and came back with new ideas that transformed the Mediterranean world. British regiments served the world over during the empire, while European colonial forces frequently served outside their homelands. Contemporary Americans may travel abroad much less than Europeans, but their military is based around the world. There is an entire history of military 'traveling cultures' overlooked by globalization studies. 
As James Clifford (1997) argues, travelers encounter cultural difference which can lead to reassessments of home. Just one example indicative of the richness as well as significance of military traveling cultures comes from Indian soldiers serving on the Western Front in the First World War. They drew comparisons between Europe and India, seeing their homeland as backward and, especially, impoverished and they identified the differences they thought were holding India back, such as excessive spending on rituals, arranged and child marriages, and poor education (Omissi, 1999, p. 19). 'When I look at Europe, I bewail the lot of India', one wrote home (Omissi, 1999, letter 448). The contrast between the social roles of Indian and European women was striking to Indian soldiers, especially in wartime Europe where women were filling jobs vacated by men at the front. One sent home the picture of an American female aviator: 'I want you to study it and see what the women of Europe and America are doing ... The advancement of India lies in the hands of the women' (Omissi, 1999, letter 654).

Robertson suggests that as people become aware of the wider world they compare places to one another, critiquing them and assessing their chances for survival and flourishing in an interconnected world. How does India match up to Europe, Indian soldiers were driven to ask. Wounded Indians in hospital were particularly surprised that European nurses cleared away the contents of their bedpans, a task reserved for very low caste servants in India. Such simple novelties could draw attention to the role of caste in structuring relations in India to acute observers. In many respects, British rule in India rested on the maintenance of traditional religious ideas, illiteracy and caste division. Ideas about popular education, overcoming superstition, and Indian social and economic development could easily lead to a critique of British rule and anti-colonial consciousness of the kind much in evidence in interwar Indian independence politics. Travel and circulation helps generates this 'relativization' and comparison, working to make India a different place. At the same time, Indian soldiers were crucial to the allied victory in the First World War. Both are excellent examples of connection and constitution in and through war.

A final area where cultural frameworks derived from or influenced by war and the military play an often overlooked role is in consciousness of the world as a whole. Examples include 'North-South' constructions of global politics as well as conceptions of 'globality', conceiving the world as a single place, as in universalist discourses of human rights or ideas about humanity sharing a common fate. The Second World War assumes particular significance here. The worldwide character of the war meant that it was in part experienced as a common calamity (Shaw, 2000, p. 116). It gave rise to the UN system and other international institutions. It also was a significant spur to the further development of international humanitarian law and the global human rights regime. Aspects of the Cold War, in particular the nuclear arms race with its attendant possibility of the destruction of humanity, also increased concern with the global as the space of a shared fate, and did so in ways directly derived from war and military preparedness.

Given the significance of North-South constructions of the world in globalization debates, it is worth briefly considering some of the imaginative work war has done here. The 'West' travels under two names in contemporary world politics, one which plays on the West as liberal and democratic, as in the 'Western democracies', and one which refers to the vast concentrations of wealth and power found in the West, as in the 'global North' (Lewis and Wigen, 1997, p. 6). When economic matters are spoken of, 'North' is generally invoked. When matters of culture, war and peace, or human rights and liberation are spoken of, the 'West' is more commonly used. The image of the West as an enlightened but militarized and muscular liberator recoups the reality of the global North as economic exploiter, as a site of mass consumption 
in a world of horrifying need. There is thus a significant and under-remarked military dimension of Orientalism. Representations of Western military action in the extra-European world overwhelmingly invoke various historical incarnations of 'humanitarian wars', wars which seek to liberate and civilize. War plays an important role in the slippage between 'North' and 'West', one more indication of its significance for imagined geographies of global politics.

No matter how 'globalization' is constructed, as economic globalization, as transregional interconnectedness, or as consciousness of the global, war and the military play far more important roles than extant studies of globalization indicate. In a sense, this is a specific instance of a more general problem. While matters military are of enormous significance for politics and society, past and present, most scholars in the humanities and social sciences know very little about armies and war. Specialists in these latter topics return the favor. With important exceptions, studies of military affairs are most often conducted in isolation from their relation to, and significance for, wider social and political context. Even prior to the blind spots of a liberal worldview, this dialogue of the deaf produced the structural conditions in the academy for pacified forms of globalization studies.

By mapping out where war and the military intersect with globalization studies, this essay has sought to lay the basis not just for studies of military globalization or of war as a form of interconnection or even of how globalization is productive of conflict. Rather, what is needed is an assessment of the ways in which war is centrally implicated in processes of globalization. While Shaw's call for a 'war-centred social theory' perhaps overstates the case, his basic point is that war is a central determinant of social and political relations $(1988$, p. 28$)$. To the extent this is true of globalization, then any adequate account of globalization cannot attend to economic or cultural or social dimensions without also taking into account war. War and armed conflict very often have been the leading edge of transregional interconnectedness. Maintaining such interconnection in the face of resistance has often required repeated use of force, while the circulation of people, goods and ideas in world politics has often taken military form. All of this suggests that war needs to be taken far more seriously in globalization studies.

\section{Acknowledgements}

Thanks to Susan Carruthers, Tina Chen, Stefan Elbe, Theo Farrell, Mark Laffey and two anonymous reviewers for comments on earlier versions of this article.

\section{Notes}

1 As in the last National Security Strategy produced by the Clinton administration, A National Security Strategy for a Global Age, available at 〈http://www.au.af.mil/au/awc/awcgate/nss/nss_dec2000_contents.htm〉, accessed 12 August 2004.

2 President G.W. Bush, Commencement Address, University of South Carolina, Columbia, South Carolina, 9 May 2003, available at 〈http://www.whitehouse.gov/news/releases/2003/05〉, accessed 10 May 2003.

3 The term 'constitutive circuits' is taken from Brighton (2004).

\section{References}

Appadurai, A. (1996) Modernity at Large (Minneapolis, MN: The University of Minnesota Press).

Barkawi, T. (2004) Globalization, culture and war: on the popular mediation of 'small wars', Cultural Critique, 58, pp. 115-47.

Barkawi, T. \& Laffey, M. (1999) The imperial peace: democracy, force and globalization, European Journal of International Relations, 5(4), pp. 403-34. 
Bates, M. (1996) The Wars We Took to Vietnam (Berkeley, CA: University of California Press).

Bayly, C.A. (2002) 'Archaic' and 'modern' globalization in the Eurasian and African Arena, c. 1750-1850, in Hopkins, A.G., ed. Globalization in World History (London: Pimlico), pp. 47-73.

Black, J. (2004) War and the New Disorder in the 21st Century (London: Continuum).

Bobbitt, P. (2002) The Shield of Achilles: War, Peace and the Course of History (London: Allen Lane).

Bond, B. (1998) War and Society in Europe, 1870-1970 (Stroud: Sutton).

Brighton, S. (2004) The Subject of Intervention. PhD dissertation, King's College London.

Cain, P.J. \& Hopkins, A.G. (2002) British Imperialism 1688-2000, 2nd ed (Harlow: Longman).

Campbell, D. (1992) Writing Security (Minneapolis, MN: The University of Minnesota Press).

Carr, E.H. (1939) The Twenty Years' Crisis (London: Macmillan).

Carruthers, S. (1998a) 'The Manchurian Candidate' (1962) and the Cold War brainwashing scare, Historical Journal of Film, Radio and Television,18(1), pp. 75-94.

Carruthers, S. (1998b) Redeeming the captives, Film History, 10, pp. 275-94.

Castells, M. (2000) The Information Age (Oxford: Blackwell).

Clausewitz, C. von (1976) On War (Princeton, NJ: Princeton University Press).

Clifford, J. (1997) Routes: Travel and Translation in the Late Twentieth Century (Cambridge, MA: Harvard University Press).

Cohen, P. (1985) Discovering History in China (New York: Columbia University Press).

Cooper, F. \& Stoler, L.A. (eds) (1997) Tensions of Empire (Berkeley, CA: University of California Press).

Drayton, R. (2002) The collaboration of labour: slaves, empires and globalizations in the Atlantic world, c. 1600-1850, in Hopkins, A.G. (ed.), Globalization in World History. (London: Pimlico), pp. 98-114.

Duara, P. (1997) Rescuing History from the Nation: Questioning Narratives of Modern China (Chicago, IL: The University of Chicago Press).

Echenberg, M. (1991) Colonial Conscripts (Portsmouth: Heinemann).

Fanon, F. (1967) The Wretched of the Earth (Harmondsworth: Penguin).

Fukuyama, F. (1992) The End of History and the Last Man (London: Penguin).

Gallagher, J. \& Robinson, R. (1953) 'The imperialism of free trade', The Economic History Review, 6(1), pp. 1-15.

Gilroy, P. (1993) The Black Atlantic (London: Verso).

Gray, J. (2002) False Dawn: The Delusions of Global Capitalism (London: Granta).

Hall, C. (ed.) (2000) Cultures of Empire (New York: Routledge).

Hall, C. (2002) Civilising Subjects (Cambridge: Polity Press).

Harper, T.N. (2002) 'Empire, diaspora and the languages of globalism, 1850-1914', in Hopkins, A.G. (ed.), Globalization in World History. (London: Pimlico), pp. 141-66.

Held, D. et al. (1999) Global Transformations (Cambridge: Polity Press).

Hirst, P. \& Thompson, G. (1999) Globalization in Question (Cambridge: Polity Press).

Hopkins, A.G. (ed.) (2002) Globalization in World History (London: Pimlico).

Howard, M. (1976) War in European History (Oxford: Oxford University Press).

Howard, M. (1987) War and the Liberal Conscience (Oxford: Oxford University Press).

Inayatullah, N. \& Blaney, D. (2004) International Relations and the Problem of Difference (London: Routledge).

Jahn, B. (2000) The Cultural Construction of International Relations (New York: St Martin's Press).

James, C.L.R. (1994 [1938]) The Black Jacobins (London: Allison \& Busby).

Jeffords, S. (1989) The Remasculinization of America (Bloomington, IN: Indiana University Press).

Joas, H. (2003) War and Modernity (Cambridge: Polity Press).

Kant, I. (1983 [1796]) To Perpetual Peace, a Philosophic Sketch (Indianapolis, IN: Hackett).

Karl, R. (2002) Staging the World (Durham, NC: Duke University Press).

Karnow, S. (1984) Vietnam (London: Penguin).

Keegan, J. (1993) A History of Warfare (New York: Alfred A. Knopf).

LaFeber, W. (1984) Inevitable Revolutions (New York: W.W. Norton \& Co.)

Latham, R. (1997) The Liberal Moment (New York: Columbia University Press).

Lewis, M. \& Wigen, K. (1997) The Myth of Continents: A Critique of Metageography (Berkeley, CA: University of California Press).

Mandelbaum, M. (2002) The Ideas that Conquered the World: Peace, Democracy and Free Markets in the Twenty-first Century (Oxford: Public Affairs).

Marx, K. \& Engels, F. (1967 [1888]) The Communist Manifesto (London: Penguin).

McNeill, W. (1982) The Pursuit of Power (Chicago, IL: The University of Chicago Press).

Morris, D. (1997) Behind the Oval Office (New York: Random House). 


\section{T. Barkawi}

Ohmae, K. (1994) The Borderless World (London: HarperCollins).

Ohmae, K. (1996) The End of the Nation State: The Rise of Regional Economics (London: HarperCollins).

Omissi, D. (1999) Indian Voices of the Great War: Soldiers' Letters, 1914-1918 (London: Macmillan).

Ó Tuathail, G. (1996) Critical Geopolitics (Minneapolis, MN: The University of Minnesota Press).

Panitch, L. (1996) Rethinking the role of the state, in Mittelman, J. (ed.), Globalization (Boulder, CO: Lynne Rienner), pp. 83-113.

Porch, D. (2001) Wars of Empire (London: Cassell \& Co.)

Renda, M. (2001) Taking Haiti: Military Occupation and the Culture of U.S. Imperialism 1915-1940 (Chapel Hill, NC: University of North Carolina Press).

Reynolds, D. (2002) American globalism: mass, motion and the multiplier effect, in Hopkins, A.G. (ed.), Globalization in World History. (London: Pimlico), pp. 243-60.

Robertson, R. (1992) Globalization (London: Sage Publications).

Robinson, W. (1996) Promoting Polyarchy (Cambridge: Cambridge University Press).

Russett, B. (1993) Grasping the Democratic Peace (Princeton, NJ: Princeton University Press).

Schmitt, C. (1996 [1932]) The Concept of the Political (Chicago, IL: The University of Chicago Press).

Schmitt, C. (2003 [1950]) The Nomos of the Earth in the International Law of the Jus Publicum Europaeum (New York: Telos).

Schneider, G. et al., eds (2003) Globalization and Armed Conflict (Lanham, MD: Rowman and Littlefield).

Shaw, M. (1988) Dialectics of War (London: Pluto).

Shaw, M. (2000) Theory of the Global State (Cambridge: Cambridge University Press).

Smith, A. (1993 [1776]) Wealth of Nations (Oxford: Oxford University Press).

Steger, M. (2002) Globalism (Lanham, MD: Rowman and Littlefield).

Tomlinson, J. (1999) Globalization and Culture (Chicago, IL: The University of Chicago Press).

Turner, B. (1994) Orientalism, Postmodernism and Globalism (London: Routledge).

Weede, E. (2003) 'Globalization: Creative destruction and the prospect of a capitalist peace' in Schneider, G. et al. (eds), Globalization and Armed Conflict (Lanham, MD: Rowman and Littlefield), pp. 311-23.

Wolf, E. (1997) Europe and the People Without History (Berkeley, CA: University of California Press).

Tarak Barkawi is lecturer in international security at the Centre of International Studies, University of Cambridge. He is currently writing a book on the Indian Army in the Second World War. 